\title{
Study of Excretory Organ (Kidney) in Post Flexion to Fingerling Stages of Schizothorax plagiostomus (Heckel)
}

\author{
Anupama Gargya ${ }^{1}$, S. N. Bahuguna ${ }^{1}$, M. K. Upadhyay ${ }^{2, *}$ \\ ${ }^{1}$ Department of Zoology and Biotechnology, H.N.B. Garhwal University Srinagar Garhwal-246 174 Uttarakhand India \\ ${ }^{2}$ Scientist, Biotech Park Lucknow - 226021, India \\ *Corresponding Author: drmkupadhyay@gmail.com
}

Copyright (C) 2014 Horizon Research Publishing All rights reserved.

\begin{abstract}
The present study describes the development of excretory organ (kidney) in post flexion to fingerling stages of the Himalayan snowtrout Schizothorax plagiostomus (Heckel). In observation Schizothorax plagiostomus larvae having a pair of elongated kidney lies above the alimentary canal close to the vertebral column, which is divided into two parts i.e. head kidney and the trunk kidney. In post-flexion to fingerling larvae, the pronephric nephrons and tubules form immediately after the pronephric duct, which connect with the anterior most tips of pronephric duct. Pronephric tubules were convoluted in anterior side and there is a small amount of erythroid and lymphoid tissue associated with this region. At the same time caudal portion of the pronephric duct (near cloaca) starts to become broad in comparison to other parts in 2.0-4.0 cm larvae. On fingerling stage obvious tubules were found in kidney with large blast like cells (Columnar epithelial cells) between the nephric tubules.
\end{abstract}

Keywords Schizothorax Plagiostomus, Post Flexion, Fingerling, Kidney

\section{Introduction}

The kidney is perhaps one of the most complex organs (Seldin and Gibisch, 1992) determining the constitution of the stock by the integrated action of at least 12 different types of cell, precisely arranged in the shape of the nephron and supporting tissue (Drummond, 2000). In teleosts, the difference in the structure of the kidney has been recorded external as well as internal among different species. The mesonephros kidney, which has chiefly renal functions in adult fish. The structure of the head kidney in teleost consists entirely of lymphoid tissue and has no nephron (Kapoor and Khanna 2004). According to Saxen (1987) the development of the kidney can be divided into four general stages, i.e. (i) the commitment of undifferentiated mesodermal cells to a nephrogenic fate (ii) the formation of an organ primordium and the caudal growth and epithelialization of the wolffian or pronephric duct, which will eventually serve as the collecting system (iii) the induction and formation of the nephron and the cell patterning events associated with the differentiation of glomerular and tubular cell types, and concomitantly (iv) the ingrowth of endothelial cells and the formation of the glomerular capillary tuft and blood filter that coincides with the onset of nephron function. The functional larval kidney in the most of teleost fish is pronephros and in it one finds a full range of cell types typical of kidney of higher vertebrates (Drummond, 2000). The pronephros, mesonephros, and metanephros represent three distinct organs of increasing complexity that form in an anterior to posterior progression during embryogenesis (Saxen, 1987). The pronephros is the first kidney to form and in free-swimming larvae of fish and amphibious aircraft, it performs the indispensable role of blood filtration and osmoregulation (Tytler, 1988; Tytler et.al. 1996; Vize et.al.1997). Compared with the more evolved meso and metanephros, the functional pronephros is remarkably simple. In teleost, it consists of only two nephrons with glomeruli fused at the midline, pronephric tubules connecting directly to the glomeruli via a neck segment, and paired bilateral pronephric ducts that carry the altered blood filtrate outside the animal (Tytler, 1988; Agarwal and John, 1988; Tytler et.al. 1996; Drummond et.al. 1998), besides the new nephrons continue to work in the mesonephric or opisthonephric kidney well after larval development is complete (Drummond, 2000). In recounting to the diverse aspects of renal system or kidney in different species of fish as easily as in other vertebrates, a real useful work has been performed by various authors (Weller et.al., 1991; Seldin and Giebisch, 1992; Clapp and Abrahamson, 1993; Kimmel et.al., 1995; Detrich et.al., 1995; Nikaido et.al., 1997; Lechner and Dressler, 1997; Brown and Reimschuessel, 1998; Drummond, 2000; Reimschuessel, 2001). But there is no whichever information available related to the early development of kidney among the Indian fresh water fish including snowtrout. Hence an attempt has been made to know how the maturation of the kidney takes place in the larval stage of a hill stream snow trout fish Schizothorax plagiostomus from post flexion to fingerling stage. Being an important commercial as well as food fish, it is indispensable to recognize the operational evolution of kidney in the snow 
trout fish.

\section{Material and Methods}

Live brooders of Schizothorax plagiostomus (Heckel) were collected from the Glacierfed River Alaknanda located at an altitude of 540 meters at sea level, longitude $78^{\circ} 47^{\prime} 26^{\prime \prime}$ and latitude of $30^{\circ} 13^{\prime} 16^{\prime \prime}, 38.8 \mathrm{Km}$ near the Chauras-Jhulapul, Srikot, Srinagar (Garhwal) during September-October 2006 by using "cast gill net". The mature brooders were stripped for taking out the egg and melt by applying slightest pressure on the stomach. The eggs and milt were mixed with the help of bird feathers in a cleaned enameled tray for 5-10 minutes (Bahuguna, 2006). After fertilisation, the eggs were laid in the hatching trays and kept in the science lab with proper aeration for controlling temperature. From post flexion to fingerling stages with 4-8 hrs intervals 5-10 larvae were fixed in different fixatives viz. $4 \%$ formalin, $70 \%$ alcohol, calcium formal, aqueous bones, alcoholic bones, and so forth as are given by Taylor (1967), Pearse (1975), Dingerkus and Uhler (1977) and Kaji, et.al. (1996) with some modifications were used according to the local condition. After completion of fixation, the larvae were washed 2-3 times in distilled water than alcohol, till the excess of fixative comes out of the tissue, then tissue preserved in $70 \%$ alcohol for further processing. The blocks of the different larvae of different stages were prepared by serial dehydration methods using alcohol (30\%-100\%) and clearing by Xylene, then embedded in paraffin wax (E Merck Histo Paraffin wax, $54-56^{\circ} \mathrm{C}$ melting point). The wax blocks were cut in transversely and

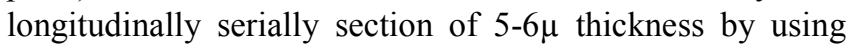
Erma rotary microtome (Japan). Mounting of sections was carried by using a thin layer of tissue and Mayer's egg albumin as an adhesive. The serially arranged tissue sections were cast on the slides and preserved along the hot plate, then a few drops of distilled water were used for spreading the sections on the coasts. After drying $\left(40-45^{\circ} \mathrm{C}\right)$, the spread slides were used for staining using Ehrlich's Acid Alum haematoxylin and eosin stain, Mallory triple staining, Heidenhain's Iron haematoxylin, Mercuric bromophenol blue and PAS reagent (Gray (1964), Taylor (1967), Pearse (1975), and Kaji, et.al. (1996) etc). After proper dehydration and clearing of stained sections, covered with a cover slip by using DPX as a mounting medium and then photomicrographs of prepared slides were taken with the help of Olympus- photo-microscope (PM-6 and PM-10).

\section{Observation}

In Schizothorax plagiostomus larvae, a Duct of the kidney lies above the alimentary canal close to the vertebral column. When the larvae are having length from $1.0-8.0 \mathrm{~cm}$ the kidney is elongated structure and is separated into two functions viz the head kidney and the trunk kidney. The middle and bottom regions of the kidney are fused, while the anterior free part represents the head kidney. The pronephros in post flexion to fingerling stage consists of a large ovoid renal corpuscle and a pair of tubules. The corpuscle is retained for fingerling stage, after which the glomerulus regresses. The glomerulas arteries come directly from the dorsal aorta. The interstitium is permeated with venous blood vessels that originate from the anterior cardinal veins and are closely apposed to the tubules. Two distinct sections of the pronephric tubular system are described by the ultrastructural characteristics of their component cells: (i) a short, transitional neck in which cells change from capsular epithelium to columnar epithelium, typical of tubules; (ii) the convoluted segment composed of cells similar to first proximal tubular cells of the opisthonephros with well formed brush borders, apical vesicles that vary in size and number along the segment, and lysosomes. Pinocytosis and exocytosis are also apparent in this section. The tubular system increases in duration and in its convolutions until about $2.0 \mathrm{~cm}$ larvae. Distally each tubule connects with a wolffian duct, with cells marked by the absence of apical inclusions and the bearing of a uniform brush border, numerous mitochondria and elaborate infolding of the basilar membrane. Histologically kidney in $1.0 \mathrm{~cm}$ length larvae of Schizothorax plagiostomus, the pronephric nephrons and tubules form immediately after the pronephric duct, which were connected with the anterior most tip of pronephric duct. Pronephric tubules were convoluted in anterior position and there is a modest amount of erythroid and lymphoid tissue associated with this region, at the same time caudal portion of the pronephric duct (near cloaca) starts to become more liberal in comparison to other percentages in $2.0 \mathrm{~cm}$ Schizothorax plagiostomus larvae (Figure. 1). In 3.0-4.0 cm Schizothorax plagiostomus larvae the urinary ducts open into a small sac (slightly broad portion) which was closely connected with the posterior digestive tract (Figure. 2). When the larvae are about $1.0-5.0 \mathrm{~cm}$ length the segmented tubules of mesonephrons were formed during the commencement of exogenous feeding or post flexion stage (Figure. 3). When the size of Schizothorax plagiostomus larvae ranged from $6.0-7.0 \mathrm{~cm}$ the hemopoietic tissues were prepared around the pronephric tubules (Figure. 3\&4). In the $8.0 \mathrm{~cm}$ larvae the coils of the mesonephric tubules became more extensive (Figure. 5\&6). In fingerling stage, obvious tubules were found with large blast like cells (Columnar epithelial cells) between the nefarious tubules in the kidney. 


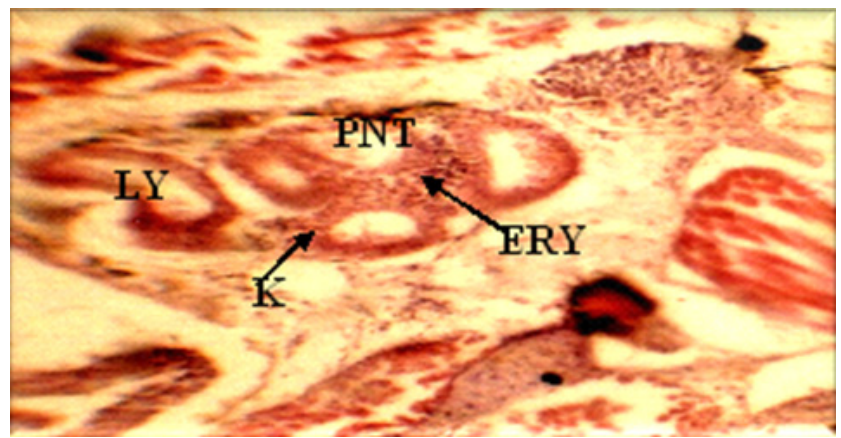

ERY $=$ Erythroid Tissue,$\quad \mathrm{K}=$ Kidney, $\mathrm{PNT}=$ Pronephric Tubules, $\mathrm{LY}=$ Lymphatic Tissue

Figure 1. T.S. of $2.0 \mathrm{~cm}$ larvae showing head kidney, pronephric tubule consists of large columnar epithelial cells, erythroid \& lymphatic tissue (100x Haematoxylin stain).

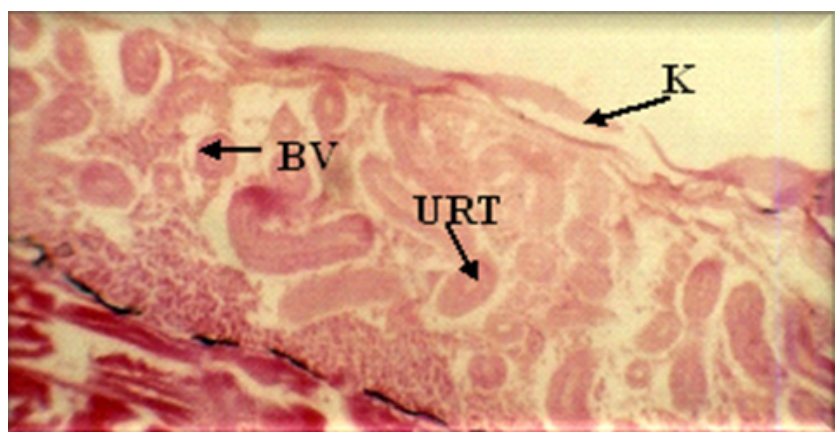

$\mathrm{K}=$ Kidney, $\mathrm{BV}=$ Blood Vessels, URT $=$ Uriniferous Tubules

Figure 2. L.S. of $4.0 \mathrm{~cm}$ larvae showing uriniferous tubules, blood vessels in kidney (100x Eosin).

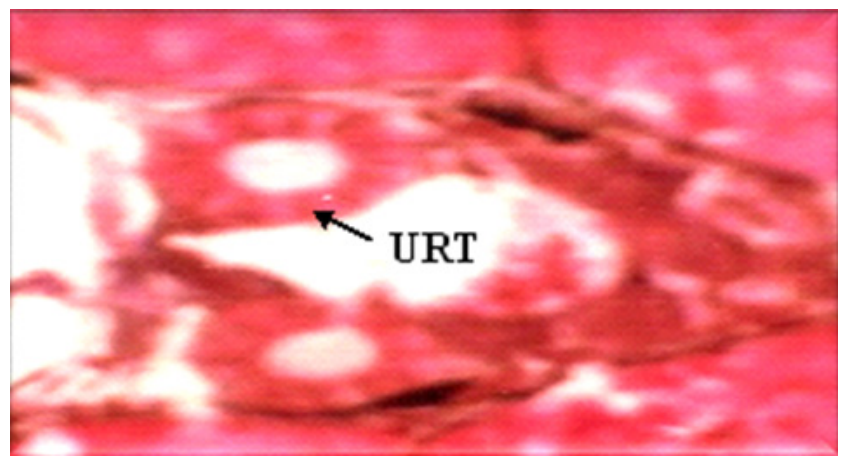

URT $=$ Uriniferous Tubules

Figure 3. uriniferous tubules of kidney (400x Eosin stain).

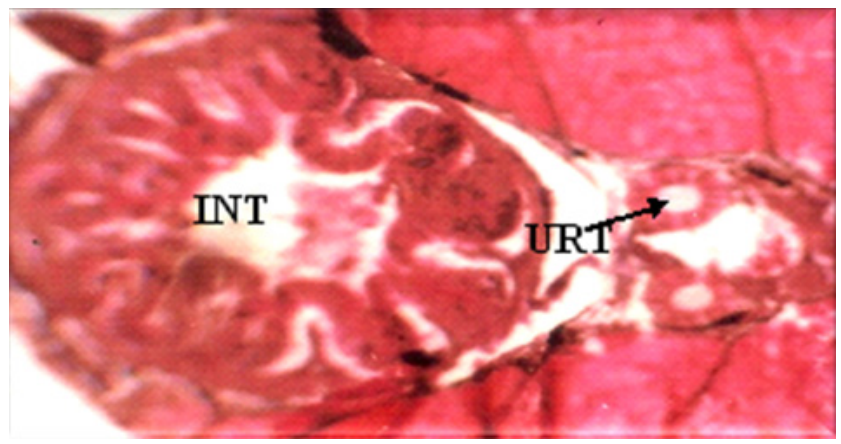

INT $=$ Intestine, URT $=$ Uriniferous Tubules

Figure 4. T.S. of $6.0 \mathrm{~cm}$ larvae showing intestine with mucous cells \& uriniferous tubules of kidney (100x eosin stain).

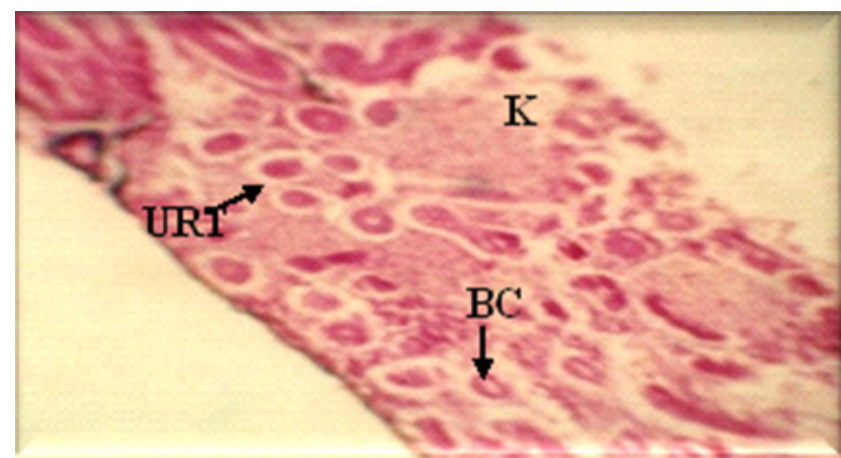

$\mathrm{K}=$ Kidney, $\mathrm{URT}=$ Uriniferous Tubules, $\mathrm{BC}=$ Buccal Cavity

Figure 5. Kidney with uriniferous tubules (400x Eosin stain).

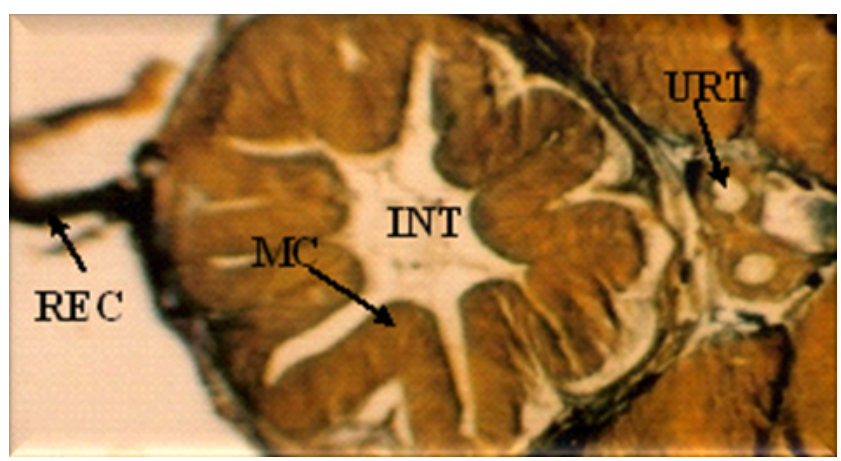

$\mathrm{MC}=$ Mucous Cell, $\mathrm{URT}=$ Uriniferous Tubules, $\mathrm{INT}=$ Intestine,

Figure 6. T.S. $6.0 \mathrm{~cm}$ larvae showing intestine with mucous cells, uriniferous tubules (100x Haematoxylin stain)

\section{Discussion}

In Schizothorax plagiostomus the renal development is almost similar to that described in other fresh water fish, but it differs in time schedule. In most of these fish, including Schizothorax plagiostomus, usually major difference in the renal system between larvae and adults is the absence of functional mesonephric kidneys during early phase of larval life. In teleost, pronephros or pronephric kidney consists of only two nephrons with glomeruli fused at the midline, pronephric tubules connecting directly to the glomeruli via a neck segment and paired bilateral pronephric ducts that carry the altered blood filtrate outside the animal (Tytler, 1988; vize et. Al. 1997; Drummond et.al. 1998) as per them all functional pronephri derive their blood supply from the dorsal aorta. Similar has been acknowledged in the present study in Schizothorax plagiostomus larvae. Pronephric premordium in amphibians and teleost fish are first apparent during early somitogenesis as a multitude of intermediate mesoderm lying under the anterior somites and future pronephros is derived from this group of cells (Kimmel et.al. 1995; Vize et.al., 1997) In Schizothorax plagiostomus larvae the pronephric duct differentiates from kidney premordia earlier to the pronephric nephrons and tubule. Similar has been suggested by Tytler (1988); Tytler et.al. (1996); Drummond et.al. (1998) and Drummond (2000) in different fish. In some genera of fish (Fierasfer Zoarces, Lepadogaster) pronephros remains functional throughout life (Lagler et.al. 1977). In most vertebrate pronephros 
degenerate and anterior most part become gradually hemopoietic; called head kidney, as the mesonephros develops (Drummond, 2000; Reimschuessel, 2001). As with the development, the process progressed anterior to the posterior end. In the present study such type of phenomenon has been mentioned in the post-flexion stage. The mesonephros is the functional kidney of adult teleosts and it is also functional in the mammalian embryo (Martino and Zamboni, 1966; and Tiedemann, 1976) in different developmental stages supporting our finding in Schizothorax plagiostomus larvae where the functional development was after post-flexion stage. The mesonephros arises from the nephrotome in more posterior segments. The tubular outgrowths, Bowman's capsule and glomerulus, form in a style similar to that of the pronephros (Goodrich, 1958). The nephrotome consists of a whole wad of cells near the pronephric excretory duct. A cavity forms in the middle of this mountain and forms the renal vesicle. As it matures, the vesicle is the first $\mathrm{C}$-shaped, but soon develops an S-pattern. The medial end of the ' $\mathrm{S}$ ' invaginates further development into the glamorous with an outgrowth forming the peritoneal funnel. The rest of the ' $\mathrm{S}$ ' becomes the primary tubule. The tubule grows out and fuses with the pronephric excretory duct, which eventually becomes the mesonephric or Wolffian duct. Secondary and tertiary tubules develop from nephrogenic blastema of the nephrotome, elongate, and combine with the primary tubule, forming a collecting tubule. The tertiary tubules open into the secondary tubules. The tubules all elongate, coil, and intertwine, producing the mesonephros (Reimschuessel, 2001). The same process supports the developmental stages in Schizothorax plagiostomus larvae from post flexion to fingerling stage. The development of mesonephros was continuing (during post flexion stage). Similar has been suggested by Drummond (2000) in the reference of some other teleosts. A gradual increase in the amount of erythropoitic and lymphatic tissue in the kidney and other lymphatic organs (thymus, spleen) was noticed in Schizothorax plagiostomus larvae (Postflexion stage) which show the growth of cell mediated immune reaction. The thymus and kidney is considered the major primary lymphoid organs. The kidney is the equivalent of bone marrow of adult mammals, as a source of 'B' lymphocytes (Zapata, 1979; Zapata et.al, 1996; Zapata and Amemlya, 2000), supporting the cellular development in the hill stream Snow-trout larvae.

\section{REFERENCES}

[1] Agarwal, S. and John, P.A. (1988): Studies on the development of the kidney of the guppy, Lebistes reticulates. Journal of Animal Morphology \& Physiology. 35: 17-24.

[2] Bahuguna, S.N. (2006): Morpho-functional developmental study of Garhwal Himalayan snow trout Schizothorax plagiostomus (Heckel) Larvae from post hatching to yolk absorption stages. Final technical report submitted and adopted ICAR, Krishi Bhawan New Delhi.

[3] Brown, M. and Reimschuessel, R. (1998): Nephron neogenesis in an aglomerular fish. Annual Meeting of the Society of Expeimental Biology, San Francisco, CA.

[4] Clapp, W.L. and Abrahamson, D.R. (1993): Regulation of kidney organogenesis: Hommeobox genes, growth factors, and Wilms' tumor. Curr Opin Nephrol Hypertens. 2: 419-429.

[5] Detrich, H.W.; Kieran, M.W.; Chan,F.Y.; Barone, L.M.; Yee, K.;Rundstadler, J.A.; Pratt, S.; Ransom, D.; Zon, L.I. (1995): Intraembryonic hematopoietic cell migration during vertebrate development. Proceedings of the National Academy of Sciences. 92:10713-10717.

[6] Dingerkus, G, and Uhler, L.D. (1977): Enzyme clearing of alcian blue stained whole small vertebrates for demonstration of carlage, stain technology.

[7] Drummond, I.A. (2000): The zebrafish pronephros: a genetic system for studies of kidney development. Pediatr Nephrol.14: 428-435.

[8] Drummond, I.A., Majumdar, A., Hentschel, H., Elger, M., Solnica-Krezel, L.Schier, A.F., Neuhauss, S.C., Stemple, D.L., Zwartkruis, F., Rangini, Z., Driever, W., Fishman, M.C., (1998): Early development of the zebrafish pronephros and analysis of mutations affecting pronephric function. Development. 125: 4655-4667.

[9] Fraser, E.A. (1950): The development of the vertebrate excretory system. Biological Reviews. 25: 159-187.

[10] Goodrich, E.S. (1958): Studies on the structure and development of vertebrates. New York Press: Dover. 657-719.

[11] Gray, I.E. (1964): Comparative study of the gill area of marine fishes. Biological Bullatin (Wooda Hole, Mass). 107: 219-255.

[12] Kaji, T., Tanaka, M., Takahashi, Y., Oka, M. and Ishibashi, N. (1996): Preliminary observation on development of pacific bluefin tuna Tunnus thynnus (Scombridae) larvae record in the laboratory, with special reference to the digestive system. Mar. Freshwater Res. 47: 261-69.

[13] Kapoor, B.G. and Khanna, B. (2004): Ichthyology handbook.Narosa publishing house, New Delhi.

[14] Kimmel, C.B.; Ballard, W.W.; Kimmel, S.R.; Ullmann, B.; Schilling, T.F. (1995): Stages of embryonic development of the zebrafish. Dev. Dyn. 203:253-310.

[15] Lagler, K.F.; Bardach, J.F.; Miller, R.R. and Passimo, M. (1977): Ichthyology. New York: John Wiley \& Sons. 91-267.

[16] Lechner, M.S. and Dressler, G.R. (1997): The molecular basis of embryonic kidney development. Mech. Dev. 62: 105-120.

[17] Leeson, T.S. and Baxter J.S. (1957): The correlation of structure and function in the nephros and metanephros of the rabbit. J.Anat. (Lona). 91: 383-390.

[18] Martino, C. and Zamboni L. (1966): A morphologic study of the mesonephros of the human embryo. Ultrastructure Res. 16: 399-427.

[19] Nikaido, M.; Tada, M.; Saji, T.; Ueno, N. (1997): Conservation of BMP signaling in zebrafish mesoderm 
patterning. Mech. Dev. 61:75-88.

[20] Pearse, A.G.E. [1975]: Histochemistry, theoretical and applied Vol. I, Churchill living stone, Edinburgh.

[21] Reimschuessel, R. (2001): A fish model of renal regeneration and development. ILAR Journal. Vol. 42(4).

[22] Saxen, L. (1987): Organogenesis of the kidney. Cambridge University Press, Cambridge.

[23] Seldin, D.W. and Giebisch, G.H. (1992): The kidney; physiology and pathophysiology, 2nd edn. Raven, New York.

[24] Taylor, W.R. (1967): An enzyme method of clearing and staining small vertebrates. Proc.United State National Museum, 122:1-17.

[25] Tiedemann, K. (1976): The mesonphros of cat and sheep. Adv. Anat. Embryol. Cell Biol. 52: 3-119.

[26] Tytler, P. (1988); Morphology of the pronephros of the juvenile brown trout, Salmo trutta.J.Morphol.195:189-204 23.

[27] Tytler, P., Ireland, J., Fitches, E. (1996): A study of the structure and function of the pronephros in the larvae of the turbot (Scophthalmus maximus) and the herring (Clupea harengus). Mar. Fres Behav. Physiol. 28: 3-18.

[28] Vize, P.D.; Seufert, D.W; Carroll, T.J.; Wallingford, J.B.(1997): Model systems for the study of kidney development: use of the pronephros in the analysis of organ induction and patterning. Dev. Biol. 188:189-204.

[29] Weller, A.; Sorokin, L.; Illagen, E.; Ekblom, P. (1991): Development and growth of mouse embryonic kidney in organ culture and modulation of development by soluble growth factors. Dev. Biol. 144:248-261.

[30] Zapata, A. (1979): Ultrastructural study of the teleost fish kidney. Dev. Comp. Immunol. 3: 55-65.

[31] Zapata, A.G. and Amemlya, C.T. (2000): Phylogeny of lower vertebrates and their Immunological structure. Curr. Top. Microbial. Immunol. 248:67-107.

[32] Zapata, A.G.; Chiba, A.; Varas, A. (1996): Cells and tissues of the immune system of fish. In: Iwama, G. and Nakanishi, T. (eds). The fish immune system,Organism, Pathogen and Environment. Academic Press. San Diego. 1-2. 